\title{
Local Cultural Heritage Sites and Spatial Planning for the Bantik Ethnic Community in Indonesia
}

\author{
Pingkan Peggy Egam ${ }^{1}$ and Nobuo Mishima ${ }^{2}$ \\ ${ }^{1}$ Doctoral Candidate, Graduate School of Science and Engineering, Saga University, 1, Honjou-Machi, Saga City, 840- \\ 8502, Japan, Lecturer at Sam Ratulangi University, Indonesia, E-mail: epingkan@ yahoo.com (corresponding author). \\ ${ }^{2}$ Professor, Graduate School of Science and Engineering, Saga University, 1, Honjou-Machi, Saga City, 840-8502, Japan, \\ E-mail: mishiman@cc.saga-u.ac.jp
}

\author{
Engineering Management \\ Received February 5, 2014; received revision April 6, 2014; accepted April 7, 2014 \\ Available online May 10, 2014
}

\begin{abstract}
The course of a city's development has an effect on both spatial and social aspects, and this situation affects ethnic communities. As a result of recent urban developments, the cultural values of a community that are embedded in living arrangements have been disturbed, thus obscuring, or even hiding, the rich cultural heritage therein. The purpose of this paper is to analyze the spatial characteristics of local neighborhoods based on a wealth of cultural heritage objects. This research focuses on the physical cultural heritage of the Bantik settlement in Malalayang. The spatial characteristics of cultural heritage objects are analyzed, based on physical and other characteristics. The results indicate that, although the Bantik ethnic community in Malalayang, Indonesia, has physical cultural heritage sites, it is unable to effectively develop these as significant cultural spaces because of the physical separation of their locations, the declining meaning of these sites to the community, and the lack of support from indigenous organizations. Distance is not the only determinant of the optimization of cultural space. Planning for cultural spaces involves three zones: 1) a promotion zone, 2) a core zone, and 3) a buffer zone. The greatest potential for developing a cultural space is in the vicinity of Minanga Road and the Niopo Stone, with the physical object reinforcement of similar sites. To improve cultural space, it is not enough to only rely on the existence of a physical object, it is necessary to create a close relationship between the object and the community with the support of indigenous organizations.
\end{abstract}

Keywords: Distance, cultural space, physical cultural heritage, spatial planning, Bantik ethnic community.

\section{Background}

In countries with a stable history (infrequent revolutions and wars, etc.), urban development is gradual, depending on underlying urban needs (Choen, 2004). However, in developing countries such as Indonesia, the urban development process causes spatial changes (along with changes in associated property rights (Christensen, 2013)), which are triggered by increased populations and the frequency of building projects (Yunus, 2006). As the city develops, the consequences of spatial planning (Yunus, 2005) and socio-economic activities (EEA Report, 2006) become an important factor in the growth of the city. Spatial planning involves the coordination or integration of the spatial dimension of sectoral policies through a territorially based strategy (United Nations, 2008). Therefore, planning is transformed into a proactive agent (Albrechts, 2004; Tewdwr-Jones et al., 2010), supported by monitoring as part of spatial planning models (Wegener, 2001). Over the last half century, a more conservationbased approach has evolved in town planning; the process extended across the historic city in the post-war period, intensified during the 1960s, and was then subsequently re-ordered following the rejection of architectural modernism. Due to the expanded scope of planning, the approach to conservation objectives had to be increasingly articulated at very different scales: city, town, village, or smaller areas within these (Larkham, 2003; Pendlebury, 2003). Translated into the arena of built cultural heritage, innovation in urban heritage governance must provide room for a new discourse of urban development (Nyseth, 2012) and the routines of governance practices (Healey, 2006).

A basic requirement (Bertolini et al. 2005) for a cultural heritage site is that it can be used as a potential source of local cultural heritage, even when there is strong pressure for other uses of the site, or pressure for urban development in the local vicinity. The accelerated pace of heritage resource creation is a widely implemented contemporary phenomenon (Graham et al., 2000; Hewison, 1987). Cultural heritage strongly reflects the influence of inter-related and powerful environments (Prinder, 2003). Cultural heritage is an expression of a community's lifestyle and is passed on from generation to generation. These include the customs, practices, places, objects, artistic expressions, and values. Cultural heritage is an asset that can be used as an element of cultural identity in 
the face of globalization (Li, 2007). Cultural heritage is often expressed as either intangible or tangible cultural heritage (ICOMOS, 2002) and in the concept of spirit of place (ICOMOS, 2008).

The degradation of a cultural heritage site often occurs because of urban development, including problems of site access. City development has an effect on both spatial and social aspects, and this situation affects ethnic communities, such as the community degradation phenomenon (Egam et al., 2012) in ethnic communities. An ethnic community is a stable group of people that historically develops as a tribe, nationality, or nation, with a common language and/or territory (Arash, 2001). Members of an ethnic community will often share a similar background (Hui et al., 2012). The community can be defined as a group of people who share a geographic area and are bound together by a common culture, values, race, or social class (Pacione, 2001). The communities examined in the research are regarded as locality-based communities; hence, they are called local communities (Jimura, 2011).

In this paper, we look at one such ethnic community, the Bantik tribal settlement, which is located on the Malalayang coast near Manado City in Indonesia, as shown in Fig. 1. There are several Bantik cultural heritage objects at sites in the Malalayang District that are associated with this particular ethnic community, which are shown in Fig. 2. The sites are dominated by stone objects of approximately 1-2 $\mathrm{m} 3$, but they are not developed (as shown in Table 1). Bantik cultural heritage tends to be obscured, and even hidden, by recent urban developments. These include the incursion of non-Bantik residents into the settlements, the displacement of Bantik families to the edges or outside of the settlements (Egam, 2012), and the movement of Bantik people to urban areas. This cultural heritage is in the form of objects, such as stones, which have a wealth of cultural and local history and have become somewhat neglected. As a result, the cultural values of the community related to living arrangements have been disturbed. The attitudes of the local people (Jimura, 2011), including a low sense of belonging and a diminished appreciation of cultural heritage among the younger generation, are all leading to the abandonment of local culture and heritage. This situation is exacerbated by the lack of good spatial planning at the sites and the lack of infrastructure, such as access to and between objects. This case study gives an example of the continuity of support for the social, institutional, and environmental aspects of human society, as well as for the non-human environment (Chang, 2007). In keeping with efforts to maintain local settlements and support Manado City, government programs have aimed at optimizing local potential as the driver of tourism to the city.

\section{Cultural Heritage}

\subsection{Cultural Heritage of the Bantik as an Alifuru Community}

Alifuru is a local term used to refer to the Indonesian native society (Grafland, 1991), particularly, in this case, the indigenous people of northern Sulawesi. In such a society, cultural heritage objects exist as a representation of the community's belief system and may have mystical value. In Bantik society, rocks, objects, and the space that surrounds them are used as sacred places with magical powers, and there is a relationship between the objects. The space around objects is a sacred buffer, and the value of the objects and surrounding space is considered in terms of abstract mystical beliefs.

\subsection{Cultural Heritage after the Influence of Christianity}

The Christian religion became a source of influence in the region after the arrival of the Dutch approximately 1700 (Sumolang, 2010, Naas, 2007). Their arrival led to changes in the meanings given to Bantik cultural heritage. New meanings were given to old objects, and meanings also became mixed-up. For example, there were changes in the meanings of the space surrounding some cultural objects, such as the Crocodile Stone, the Niopo Stone and so on. Previously, people believed that this site had magical power, but after the influence of the Christian religion, it is no longer considered a place with supernatural powers. However, in the culture of the native Bantik community in Malalayang, sacred and private spaces remain strongly connected to territory. Despite this, private space exists without the communal rituals that it was once connected to.

\subsection{Heritage under the Influence of Urban Pressure}

The biggest changes to cultural heritage sites are brought about by market forces (Simmie and Martin, 2010), which lead to development pressure on the areas surrounding cultural objects. Therefore, the spaces around cultural objects, such as the Lrana Stone, the Kuangang Stone, the Crocodile Stone, and Ake Minanga, have come under pressure. The expansion of non-Bantik settlements and lifestyle influences have led to the loss of both the cultural spaces around these heritage objects and the meanings associated with them (as is shown in Table 3). The three biggest changes to cultural heritage sites that have been brought about by city development are as follows: 1) changes in meaning, 2) changes in activity, and 3) changes in space. The periods of Bantik community history are shown in Table 2.

\section{Research objectives and methodology}

\subsection{Research Objectives}

The aim of this paper is to analyze the spatial characteristics of the local neighborhoods based on their local cultural heritage. This paper focuses on the objects of physical cultural heritage belonging to the local community of the ethnic Bantik tribe in Malalayang. Therefore, spatial planning of an ethnic community, based on the use of the space around cultural heritage objects, is an important idea that needs to be implemented to protect local settlements. 


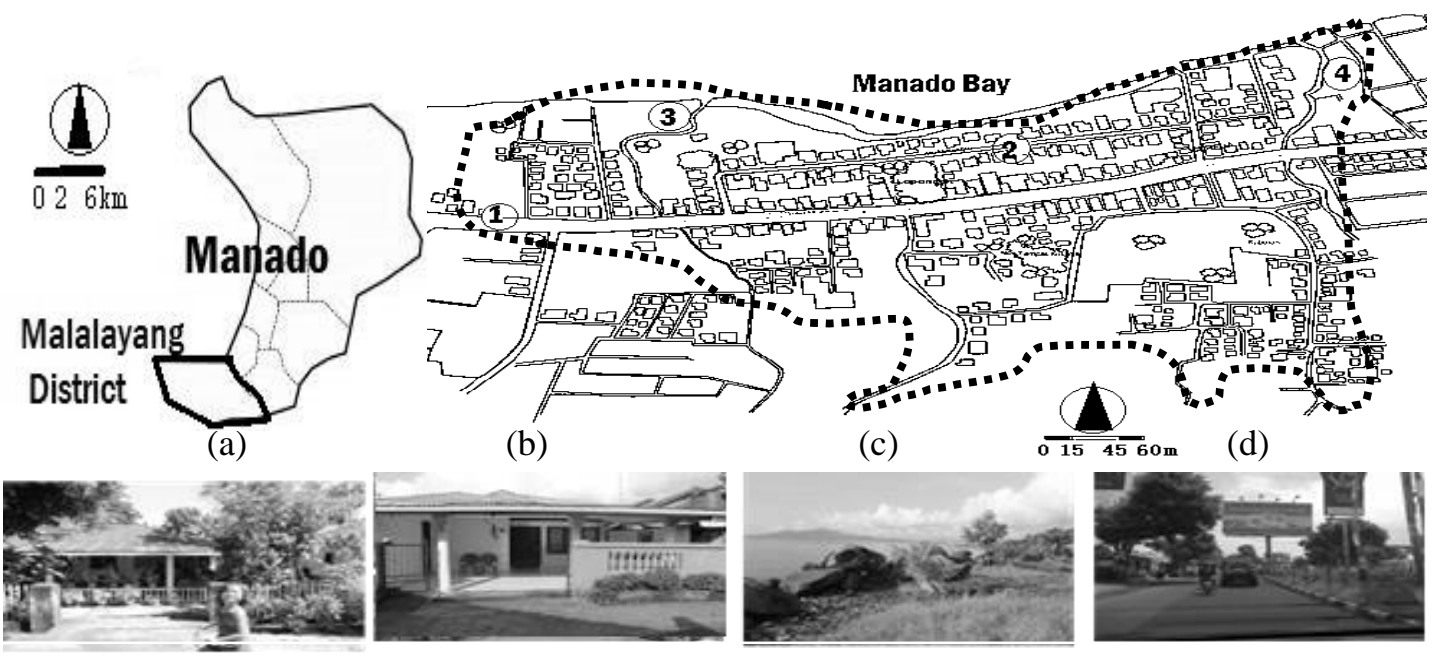

Legend:

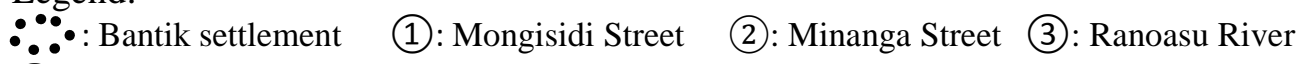
(4): Boki River (a): Around Minanga Street
(b): Bantik home
(c): Coast
(d): W. Mongisidi Street

Fig. 1. Map and the situation of the study area

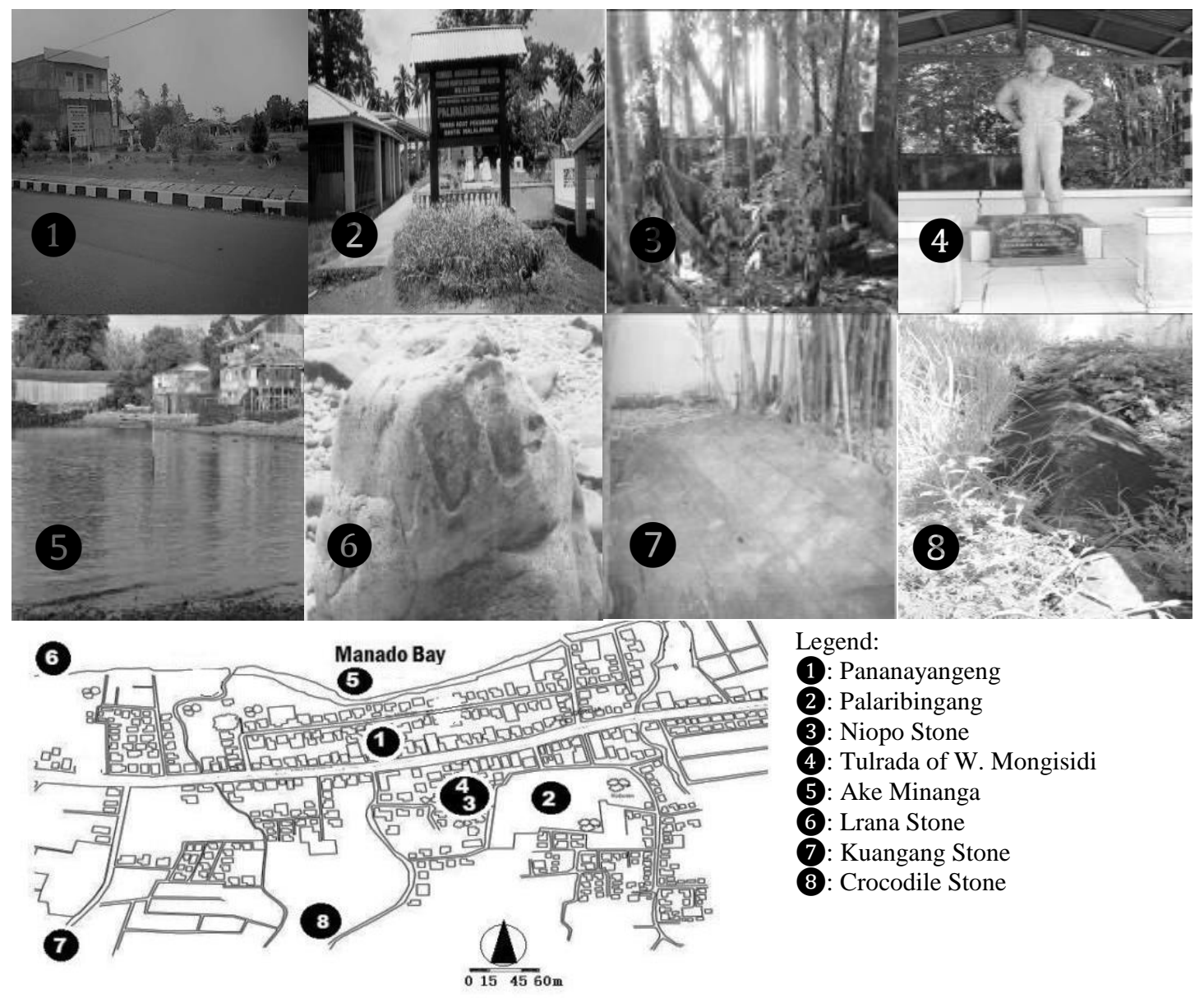

Fig. 2. Photos of Bantik cultural heritage sites and their locations 
Table 1. List of cultural heritage objects

\begin{tabular}{|c|c|c|c|c|c|c|c|c|c|c|c|c|}
\hline \multirow[t]{2}{*}{ Name of heritage site } & \multicolumn{3}{|c|}{ Type } & \multicolumn{3}{|c|}{ Material } & \multicolumn{4}{|c|}{$\begin{array}{l}\text { Size }(\mathrm{m})(\mathrm{m} 2)^{*} \\
(\mathrm{~m} 3)^{* *}\end{array}$} & \multirow[t]{2}{*}{ Natural } & \multirow[t]{2}{*}{$\begin{array}{c}\text { Artific } \\
\text { ial }\end{array}$} \\
\hline & Point & Linier & Areal & Stone & Water & Concrete & 1 & 2 & 3 & $>3$ & & \\
\hline 1)Pananayangeng & & & & & & & & & & $* *$ & & \\
\hline 2Palaribingang & & & & & & & & & & $* *$ & & \\
\hline \multicolumn{13}{|l|}{ (3Niopo stone } \\
\hline \multicolumn{13}{|l|}{ (4Mongisidi tulrada } \\
\hline \multicolumn{13}{|l|}{ 5Ake Minanga } \\
\hline 6Lrana stone & & & & & & & & & $* *$ & & & \\
\hline (7)Kuangang stone & & & & & & & & & $* *$ & & & \\
\hline 8Crocodile stone & & & & & & & & & $* *$ & & & \\
\hline
\end{tabular}

Table 2. Periods in the Bantik community history

\begin{tabular}{|c|c|c|c|}
\hline \multirow[b]{2}{*}{$\begin{array}{l}\text { Bantik community } \\
\text { period }\end{array}$} & \multicolumn{2}{|c|}{ Meaning of cultural heritage } & \multirow[t]{2}{*}{ Description } \\
\hline & Object itself & Surroundings & \\
\hline $\begin{array}{l}\text { Alifuru Community } \\
\text { (before 1700s) }\end{array}$ & $\begin{array}{l}\text { Mystical: } \\
\text { - Secret and hidden } \\
\text { - Understood by a } \\
\text { particular person or } \\
\text { entity }\end{array}$ & $\begin{array}{l}\text { Sacred space: } \\
\text { Highly } \\
\text { respected } \\
\text { space }\end{array}$ & $\begin{array}{l}\text { - Direct relationship between humans and } \\
\text { nature } \\
\text { - There is a buffer space surrounding } \\
\text { objects } \\
\text { - Territory in the context of culture } \\
\text { - Temporary barrier }\end{array}$ \\
\hline $\begin{array}{l}\text { Christian Religion } \\
\text { Community } \\
\text { (1700s-1990s) }\end{array}$ & $\begin{array}{c}\text { Mystical } \\
\text { Non-mystical }\end{array}$ & $\begin{array}{l}\text { Sacred and } \\
\text { private space }\end{array}$ & $\begin{array}{l}\text { - Causal link between man and nature } \\
\text { - There is a space between object and } \\
\text { surroundings } \\
\text { - Territory in the context of culture } \\
\text { - Temporary barrier }\end{array}$ \\
\hline $\begin{array}{l}\text { Influences of urban } \\
\text { pressure }(1990 \sim)\end{array}$ & Cultural & $\begin{array}{l}\text { Loss of sacred } \\
\text { and private space } \\
\text { Cultural space }\end{array}$ & - Ambiguity of territory \\
\hline
\end{tabular}

\subsection{Methodology}

The research focuses on the physical cultural heritage in the Bantik settlements in Malalayang. The settlements are located in four administrative sub-districts: Malalayang 1 and 2, Malalayang 1 East, and Malalayang 1 West. Before the analysis, the culture heritage objects were physically located around the coast, the main street, and the back of the Bantik settlement, based on the existing data. Data for this study was collected through questionnaires and field surveys, combined with a study of the relevant literature. Aspects of the spatial characteristics of the cultural heritage objects is reviewed, based on physical and other characteristics, including the distance, the date of the Bantik settlement around the object, and the originality of the objects.

Therefore, our spatial analysis considers three factors related to the conditions of the physical cultural heritage sites in the Bantik settlement: (1) the situation and condition of the physical cultural heritage object, based on its distance from the main street; (2) the position of the physical cultural heritage object and its location within the settlement; and (3) the structure of the zones of cultural heritage objects, which consists of the distribution zone, based on the distance from the main street. The effect of globalization has become increasingly clear at the local level (Fernandes, 2012); therefore, there is a clear need to strengthen cultural heritage and local identity. Finally, these factors will be analyzed to outline a method for cultural planning based on zone divisions. The flow of research is shown in Fig. 3.

\section{Analysis and Discussion}

\subsection{Situation and Condition of Heritage}

\subsubsection{Distance of cultural heritage from W. Mongisidi} Street

Our analysis of the distance of cultural heritage sites from the main road (W. Mongisidi Street) indicates that this has an important influence on the way people interact with cultural heritage sites. Moreover, this analysis shows that, the distance from W. Mongisidi Street also has a strong 
impact on the quality of the space. Therefore, there are several categories related to the distance of the cultural heritage site from W. Mongisidi Street. First, to promote people's interaction with the physical object, a distance of less than $100 \mathrm{~m}$ is the most effective because it encourages direct contact with cultural heritage objects. This is because people that pass along the main street come into close proximity with the cultural heritage objects. Second, the sites that lie within a distance of 100-200 $\mathrm{m}$ have the greatest cultural activities and relationships with the Bantik community. This is due to three factors: (a) the lack of intervention by non-Bantik people inside the settlements; (b) the impact of the hustle that results from high traffic density at sites that are closer to the main street; and (c) the increased privacy of the spaces that are 100 $200 \mathrm{~m}$ away. Third, we found that at sites farther than 200 $\mathrm{m}$ away, there is no significant factor that encourages people to interact with these cultural heritage objects. This is because road function is dominant over the need to access the object.

Our analysis of the street development and the distances between the main street and each heritage site are shown in Table 3. From this, we argue that there are three ways in which space has an influence, based on the distance between the main street and the cultural heritage site: (1) a distance less than $100 \mathrm{~m}$ is categorized as promotion space; (2) a distance between $100 \mathrm{~m}$ and $200 \mathrm{~m}$ is most likely to be cultural space; and (3) a distance of more than $200 \mathrm{~m}$ has limited promotion of cultural heritage (Table 4). This effect increases for distances greater than $300 \mathrm{~m}$. Although these sites are still considered cultural spaces, they can only be identified at a distance because of their lack of proximity to physical cultural heritage sites.

\subsubsection{Position of cultural heritage in the settlement}

Based on the available data, the physical cultural heritage objects can take various forms, but are mainly stones (40\%) that are large in size $(>1-2 \mathrm{~m} 3)$. As the number of Bantik in the community diminishes - due to the growth of the non-Bantik population and the outward movement of the Bantik people - the significance of each object is further weakened. These objects, and their sites, have a history of cultural value in the community, even though they tend to go unnoticed by many Bantik people. Cultural heritage sites are not concentrated in one location, but are scattered across the settlements. Based on the analysis, it is possible that the greatest weakening of attachments to these objects occurs at sites that are not close to the main Bantik population.

The relative position of these cultural heritage objects can be a classified into three groups: 1) Minanga Street surroundings; 2) east of Minanga Street and parallel to it; and 3) surrounding the cemetery to the east of the settlement. Although several of these have historical and cultural value and unique physical trace evidence, the Kuangang Stone, Crocodile Stone, and Lrana Stone have no effect on Bantik culture because the culture of a these physical objects is a considerable distance from the Bantik settlement and they are located apart from the largest Bantik community settlement.

\subsection{Structure of the Cultural Heritage Objects Zones}

The heritage sites are divided into several zones. These are: around the coast, near residential locations, and apart from residential locations. An analysis of the cultural heritage site positions and their distances from each other reveals that the Bantik cultural space is created by individuals' activities, and, in particular, their physical and social relationships (Higgins, 2007). A meaningful cultural space is created within distances of up to $200 \mathrm{~m}$ because at this distance it is very likely that cultural activities will occur. Cultural spaces beyond that distance are more defined by their physical heritage than their meaning, as there is a much lower probability of cultural activities occurring more than $200 \mathrm{~m}$ from the largest concentrations of Bantik people. This distance is better understood as cultural space with a category and symbolic meaning, as shown in Table 5. What is needed is a close relationship between the physical culture and the cultural activity because there are some physical objects outside the zone of greatest concentration of the Bantik people in the settlements.

Factors of space, time, and distance reduce the quality of family relationships in the settlements, resulting in the cultural space becoming ambiguous. The distance between the location of cultural heritage objects, the main road, and the concentration of dispersed residential locations of the Bantik society affects the structure of cultural space zones. As such, care must be taken when zoning cultural space, in particular by involving communities and indigenous organizations to delineate the physical cultural heritage. Appropriate zoning is needed to strengthen local identity and to improve the quality of relationships in the ethnic community. Furthermore, to strengthen local identity, quality relationships are needed to strengthen the relationship to cultural spaces. Based on questionnaires, $90.9 \%$ of individuals chose Bantik field as being representative of cultural activity. These results are based on activities that involve the whole Bantik community because the field is one of the focal spaces of Bantik tribal life in Malalayang. Many activities can take place in Bantik field. Furthermore, the court has publicly ruled that cultural activities are the right of the Bantik settlements and that tribal communities have the right of permanent residence in this area. However, based on a location analysis, the field is a public space and has a high value for Bantik society. Based on these results, a field is a prestigious representation of Bantik cultural space. Zoning of the cultural space extends northward from Minanga Street in an area bounded by the coast. The location is the site most likely to serve as the core zone of cultural space. Cultural spaces are also seeping into the southern settlements, especially around the cemetery, although these have different services and activities associated with them. The field is also used as the central unifying space for the Bantik communities in Malalayang. In recent years, heritage has enjoyed increasing attention from policymakers and is now seen as an important resource for economic growth (Vaz, 2011). Therefore, this location has social importance and meets the basic needs of the settlement. 


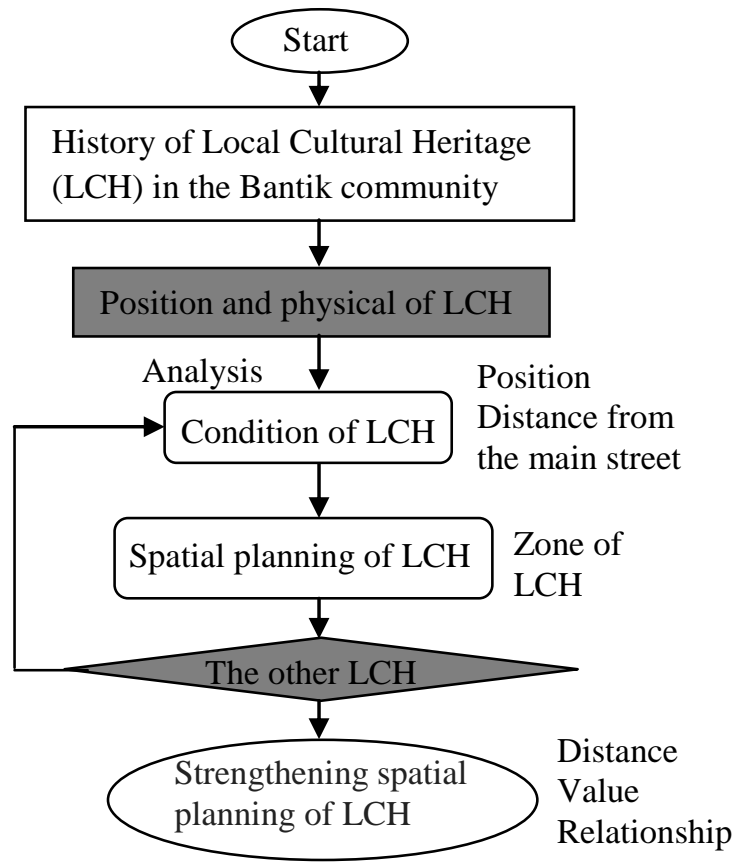

Fig. 3. Flow of research on local cultural heritage

Table 3. Influence of the development along W. Mongisidi Street on culture heritage sites

\begin{tabular}{|c|c|c|}
\hline \multirow[t]{2}{*}{ Condition and Distance } & \multicolumn{2}{|r|}{ Analysis } \\
\hline & Before the $1990 \mathrm{~s}$ & After the 1990s \\
\hline General conditions & $\begin{array}{l}\text { - The width of the road: } 8 \mathrm{~m} \\
\text { - Lack of limiting lane road }\end{array}$ & $\begin{array}{l}\text { - The width of the road } 16 \mathrm{~m} \text { equipped with a } \\
\text { roadblock } \\
\text { - Addition of an alternative path for direct access } \\
\text { to residential areas } \\
\text { - Increased density }\end{array}$ \\
\hline \multicolumn{3}{|l|}{ Distance (m) } \\
\hline & - No direct access to the object except & $\begin{array}{l}\text { There are two categories of relationships with } \\
\text { culture heritage: }\end{array}$ \\
\hline$<100$ & $\begin{array}{l}\text { through a field } \\
\text { - No direct contact with the public, } \\
\text { unless through the court } \\
\text { - Located in a residential area } \\
\text { - In a private space }\end{array}$ & $\begin{array}{l}\text { 1) Direct relationship with an object: } \\
\text { - Can see it directly from the main road Located } \\
\text { on a public access to the city and a main } \\
\text { corridor } \\
\text { - Conveniently located in a commercial area } \\
\text { - Less private space } \\
\text { 2) Indirect link with the object: } \\
\text { - In a residential environment with a dominant } \\
\text { Bantik community } \\
\text { - Less private space }\end{array}$ \\
\hline $100-200$ & $\begin{array}{l}\text { - No direct relationship with the object } \\
\text { - Several buildings block the object } \\
\text { - No contact with the hustle of the } \\
\text { main street }\end{array}$ & Does not have a direct relationship with the object \\
\hline $200-300$ & $\begin{array}{l}\text { - No relationship with the object } \\
\text { - No effect on the object }\end{array}$ & $\begin{array}{l}\text { Located outside the residential center } \\
\text { No effect on the object }\end{array}$ \\
\hline$>300$ & $\begin{array}{l}\text { - Does not have a relationship with the } \\
\text { object }\end{array}$ & $\begin{array}{l}\text { Located outside the residential center } \\
\text { No effect on the object }\end{array}$ \\
\hline
\end{tabular}


Table 4. Categories of distance between the main street and the cultural heritage site

\begin{tabular}{cc}
\hline Distance $(\mathrm{m})$ & Space categories \\
\hline$<100$ & Promotion space \\
$100-200$ & Cultural space \\
$200-300$ & Low cultural space \\
$>300$ & Low cultural space \\
\hline
\end{tabular}

Table 5. Cultural heritage categories

\begin{tabular}{ccc}
\hline Distance $(\mathrm{m})$ & Objects & Category \\
\hline$<100$ & Pananayangeng & Cultural space based on cultural activities \\
& Palaribingang & \\
$100-200$ & Sclupture of W & \\
& Mongisidi & \\
$200-300$ & Niopo Stone & Cultural space based on symbolic meaning \\
& Ake Minanga & \\
& Lrana Stone & \\
& Kuangang Stone & \\
& Crocodile Stone & \\
\hline
\end{tabular}

\section{Spatial Planning}

\subsection{Methods for Planning a Cultural Space}

Spatial planning is defined as a method used largely by the public sector to influence the future distribution of activities on a landscape (European Commission, 1997). Several problems underlie cultural planning in this context. These include a variety of cultural heritage object types differentiated between the two locations that are separated by a main road and the coastal areas that contain a high concentration of Bantik community members. Three zones must be considered for planning cultural space in the Bantik settlement: (1) a promotion zone; (2) a core zone; and (3) a buffer zone. The arrangement of space, especially with respect to the stones object, is what causes low public awareness of cultural heritage sites. The distance from the main street is an important factor when objects are positioned in the center of the settlement. The conceptual distribution of spatial and physical objects needs to take into account their distance from areas with the highest concentration of Bantik community members and their distance from the main street, as shown in Fig. 4.

Planning details need to be adjusted to suit the characteristics of the location, in particular the existing division of cultural space. Planning involves not only the physical arrangement of space but also surrounding community activities, cultural activities, rules and policies, as well as the maintenance of cultural heritage objects and the spaces around them. This is shown in Table 6. The loss of cultural identity tends to be caused by the erosion of cultural activities, the influence of W. Mongisidi Street, and the distances between objects that are located in prime locations in relation to the Bantik settlements. Government cooperation and support are essential for the establishment of zoning laws and to assist in the maintenance of the objects and the area that surrounds them.

\subsection{Cultural Space Planning for an Ethnic Community}

The notions of urban sustainability and "living cities" are characterized by their possession of unique historic heritage (Vaz, 2011). Cultural frameworks and socioeconomic contexts provide an understanding of traditions, value systems, and symbols that are common to a given society (Landman, 2009). This understanding is in contrast to the existing situation in the local community. The development of the city has changed the collective local memory; therefore, the existing cultural heritage has almost no meaning. In contrast, the cultural heritage activities are themselves symbols that can be used to create an identity for local communities. The wealth of cultural heritage is the dominant factor, and this is connected with cultural planning. Therefore, coastal locations produce a grouping effect, acting as an attraction for residents by possessing value associated with early historical settlements located around the coast. The planning needs to be supported by local attitudes. The 1990s generation, in particular, expressed poor attitudes (only 15\% of respondents) toward viewing cultural heritage as important. This contrasts with the older generation (aged 40 years and above), who had fairly positive attitudes (45.7\% of respondents) about cultural heritage. This shows that there is still hope for developing higher levels of respect towards cultural heritage in the younger generation through the optimization of existing indigenous organizations. These include the "Young Generation of Bantik Tribes," the "Institute of Indigenous Stakeholders of the Bantik Minanga Tribe in Malalayang," the "Alliance of the Bantik Tribal Society," and the "Social Organizations of the Bantik" including the following: Tontey family, Bangkang family, Rumansi family, Rumansi family, Sege family, Pokatong family, Mongisidi family, and the None family.

\section{Effectiveness of Spatial Planning}

Further analysis is directed at the physical cultural heritage objects around the coast that are in danger of disappearing altogether due to neglect, as shown in Fig. 5. Most Bantik 
do not realize that these objects have significance to the Bantik people and their settlement in Malalayang. In their responses to our questionnaire, approximately $60 \%$ of the respondents were only aware of the Boki River and the Ranoasu River as physical objects without significant cultural meaning to them. However, the initial historical Bantik settlement in Malalayang was located between these two rivers. Furthermore, the two rivers are the main sources of water in the settlement. The springs of Kakukudang, located near the coast, are even more neglected in the public consciousness. Approximately $95 \%$ of the respondents had no knowledge of these springs.

\subsection{Distance and the Cultural Value of the Sites}

The Boki River and the Ranoasu River are located on sites that we categorize as promotion spaces. Furthermore, the Lrana Stone is in a position promotion space because it is located less than $100 \mathrm{~m}$ from the main road. Although these objects are in prominent spaces; this is not sufficient to designate either of the rivers or the Lrana Stone as promotion zones because they all have low cultural value for Bantik society in Malalayang at present. Therefore, the Lrana Stone is positioned far from the largest concentration of the Bantik residential community in Malalayang. Furthermore, based on the data from the questionnaires and interviews on Bantik community, 90\% of respondents did not know that the Lrana Stone is part of the Bantik community's heritage. Further action needs to be taken for the Lrana Stone to be transformed into the core zone. The situation is different for the Crocodile Stone and the Kuanga Stone. Both stones are located away from the main road and the Bantik residential areas, and both stones are in isolated locations. The objects have no meaning for the Bantik community; therefore, by analyzing the locations of these objects, we can see that their isolation makes them unlikely to be viewed as significant culture heritage sites. Therefore, our spatial analysis needs to take into account, in particular, the arrangement of surrounding locations.

\subsection{Spatial Value}

Bantik Field and the cemetery have a high potential for cultural and social significance because they are within a strategic distance, and they are in direct contact with the main transport lines. In our spatial analysis, images of the cemetery were identified as a social space, and secondly, as a cultural space. This is because the function of the cemetery is focused on one of the primary social needs. However, the cultural space started to decline in importance when the object's lost direct contact with the main transport routes and Bantik settlements. Based on the spatial analysis, we suspect that the Niopo Stone and cemetery had a fairly close relationship in the past because the two objects are very close to each other. The Niopo Stone has a high value for community safety, whereas the cemetery is in the outer settlements that are valued for tranquility.This has considerable potential, because the community views the site in positive cultural terms and as part of the settlements. The construction of spatial value is shown in Table 7. However, in this case there has been a shift in the understanding of the object due to the influence of Christianity. This changes the meaning, along with the understanding of the development of the city and is given significance by the community.

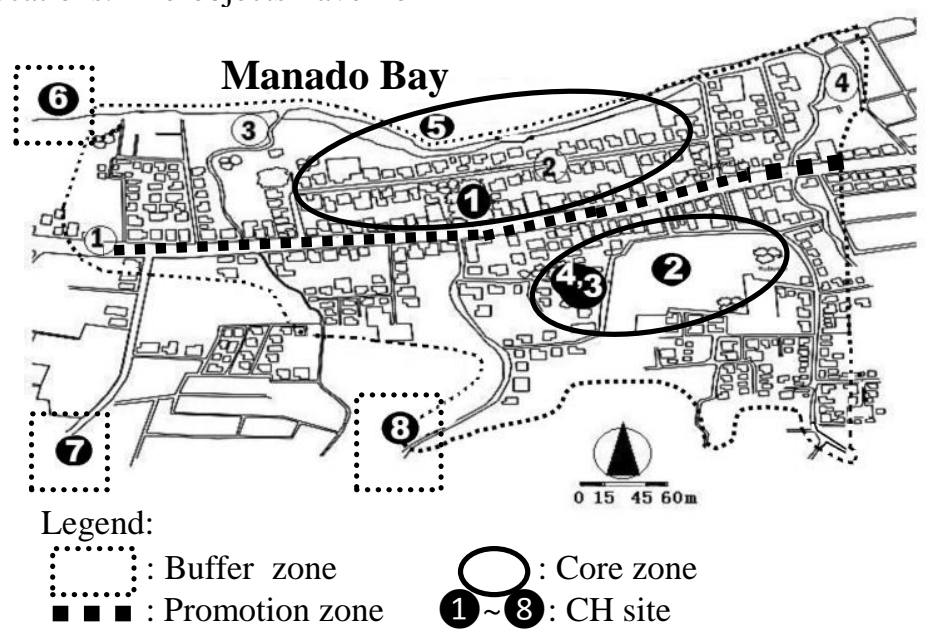

Fig. 4. Conceptual distribution of zone considering the distance from the main street

Table 6. Methods for planning cultural space

\begin{tabular}{ccc}
\hline Distance $(\mathrm{m})$ & Problem & Planning Method \\
\hline$<100$ & Varied tangible cultural heritage & Promotion zone \\
$100-200$ & A strong influence from the main street & Core zone \\
$200-300$ & Separated by the main road & Buffer zone \\
$>300$ & Two characteristic locations & Separated from largest concentration of Bantik society \\
\hline
\end{tabular}




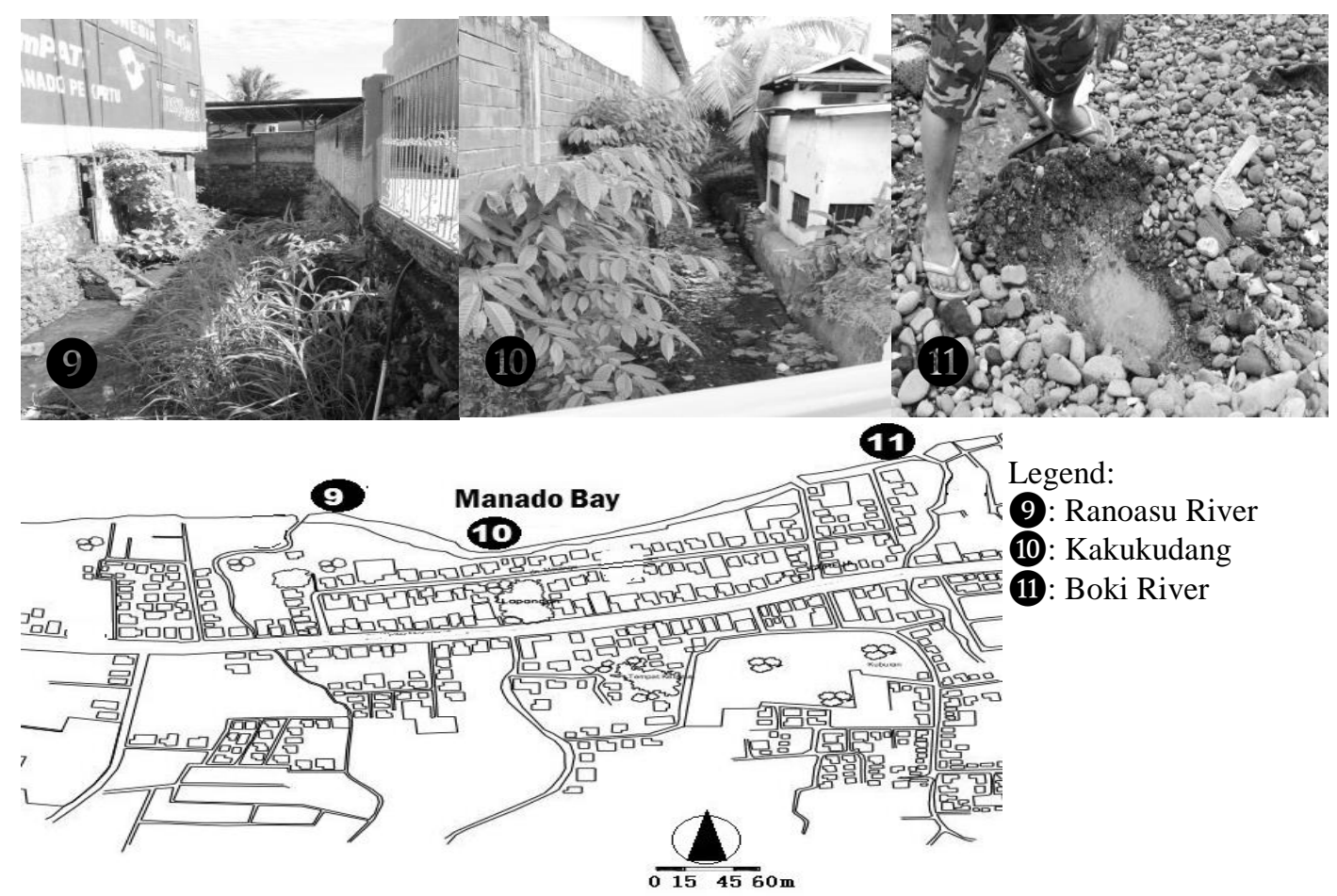

Fig. 5. Photos of cultural heritage objects around the coast are barely recognizable

\subsection{Relationship Between Cultural Spaces and the Bantik Community}

It is possible to improve the quality and position of the cultural heritage by improving the connection between existing cultural heritage sites and the community. This can be achieved by taking a more holistic planning approach and by promoting spatial planning methods that strengthen the community's physical and social support structures. One of the obstacles encountered in the planning, based on the above conditions, is the separation between cultural heritage locations and the Bantik residential areas. The issue of spatial distance can be solved by strengthening the relationships within Bantik society with the power of indigenous organizations.

It would also be useful, at a later stage, to encourage the development of a close relationship between the three planned zones, that is, the core zone with the promotion zone, the core zone with the buffer zone, and the buffer zone with the promotion zone. This relationship is created by spatial and social activities, which need to be strengthened by addressing the issue of distance and the spatial characteristics of the location. This should lead to an increase in local activity-based culture, and should lead to an improvement in the quality of the physical objects, as shown in Fig. 6. Overall, this increase should be based on local identity. The strength of local identities is achieved through the promotion zone planning method, and the core zone and buffer zone, as well as through social reinforcement in the form of strengthening familybased indigenous organizations.

\section{Discussion}

The situation and conditions of cultural heritage were analyzed based on the distance between the physical objects of cultural heritage, the main roads, and the largest concentrations of Bantik public housing. The residential locations are the sites of the early settlements that were established by the Bantik people in Malalayang. One part of this analysis is the cultural atmosphere, which generates categories of cultural space. The categories of this cultural space were further analyzed to produce the structures of the space. Planning methods are needed to sharpen and develop the structures of this space. The method of planning related to this spatial layout involves the arrangement of cultural heritage into three zones: the promotion zone, the core zone, and the buffer zone. If a location has cultural heritage associated with it, then the distance usually has a profound influence on the category of the cultural space. Looking at the distance between the object and the main road, we found that a distance of less than $100 \mathrm{~m}$ has the potential to render the site as a core zone because it is directly proximate to the main road.

A distance of less than $100 \mathrm{~m}$ does not fully delimit the core zone because the significance of cultural heritage objects is not in itself enough to establish a spatial image. A strong cultural heritage spatial image occurs at a distance of 100-200 m, which remains at a sufficient distance for the object to serve as the focus of a core zone. Physically, the strengthening of the cultural heritage image is reinforced by inserting physical cultural heritage objects into residential locations with the largest concentrations of people - such as in the coastal area, as well as in the vicinity of the main road.

However, these locations do not always strengthen the spatial images of cultural heritage sites. This is demonstrated by the neglect of some objects, from public indifference, and the lack of a role for indigenous organizations in maintaining heritage for the community. One problem for maintaining the integrity of the cultural heritage sites as a whole is the variety among the existing objects and sites. The application of planning methods could address this holistically through the categorization of spaces into several zones; that is, the promotion zone, the core zone and the buffer zone. One of the main reasons 
that people engage in planning for a community is to protect what they value about it (Kelly, 2009). Therefore, strengthening the quality of the space and its facilities, coupled with the establishment of relationships between the objects within the community, need to be taken into account; this will lead to the strengthening of community identity. Consequently, repairing and strengthening sites is a priority, in accordance with the specifics of each location, and the objects and activities associated with them. There is a strong necessity to obtain planning method specifications for such developments.

The strengthening and effectiveness of cultural planning is associated with three aspects: (1) the cultural heritage and the location of surrounding objects related to the site's significance; (2) the natural fascination about coastal areas (in the study of cultural heritage, coastal areas are often associated with objects of cultural value); and (3) the need to improve the relationship between communities and indigenous organizations. Residents' feelings about their relationships with their neighbors have a strong influence on the formation of communities. Therefore, it is important to include performance criteria and physical elements in planning detached housing areas in communities (Kwack, 2004). Based on a literature review and an analysis of social relationships, especially of relationships based on cultural heritage objects within the Bantik community, it is clear that forming social relationships between the communities and the indigenous organizations is one means of achieving cultural reinforcement and maximizing space. Therefore, the issue of distance is not a significant barrier to achieving the optimization of cultural heritage in the community. Based on the level of cultural space, recommendations can be made about the spacing of objects, thereby creating relationships between objects that are intact and with other objects that require preservation, as shown in Table 8 .

\section{Conclusion}

Cultural space is created from the relationship between physical space and objects, cultural activities, and the surrounding space. Although the Bantik community in Malalayang possesses a rich cultural heritage, its local potential is not optimized. This results in the blurring, and even the loss of cultural practices and identification. This process is influenced by distance, the position of cultural heritage sites, the low level of activity of the Bantik people, and the diminishment of cultural activities due to urban development. The greater the distance between the people, and the diminishment of cultural activities due to object, the areas of highest Bantik population concentrations, and the main road, the more undermining of the original cultural space occurs. Conversely, when objects are in close proximity to the main road, this will reduce the originality of the cultural atmosphere. The core zone for the creation of a cultural space can be found at a distance of 100-200 $\mathrm{m}$ from the main road, with locations around Minanga Street. This corresponds to early settlement locations of Bantik society. To this day, these areas have the largest concentration of Bantik people in the settlement. A distance of less than $100 \mathrm{~m}$ serves as the promotion zone, whereas the other locations with physical cultural heritage are used as a buffer zone.

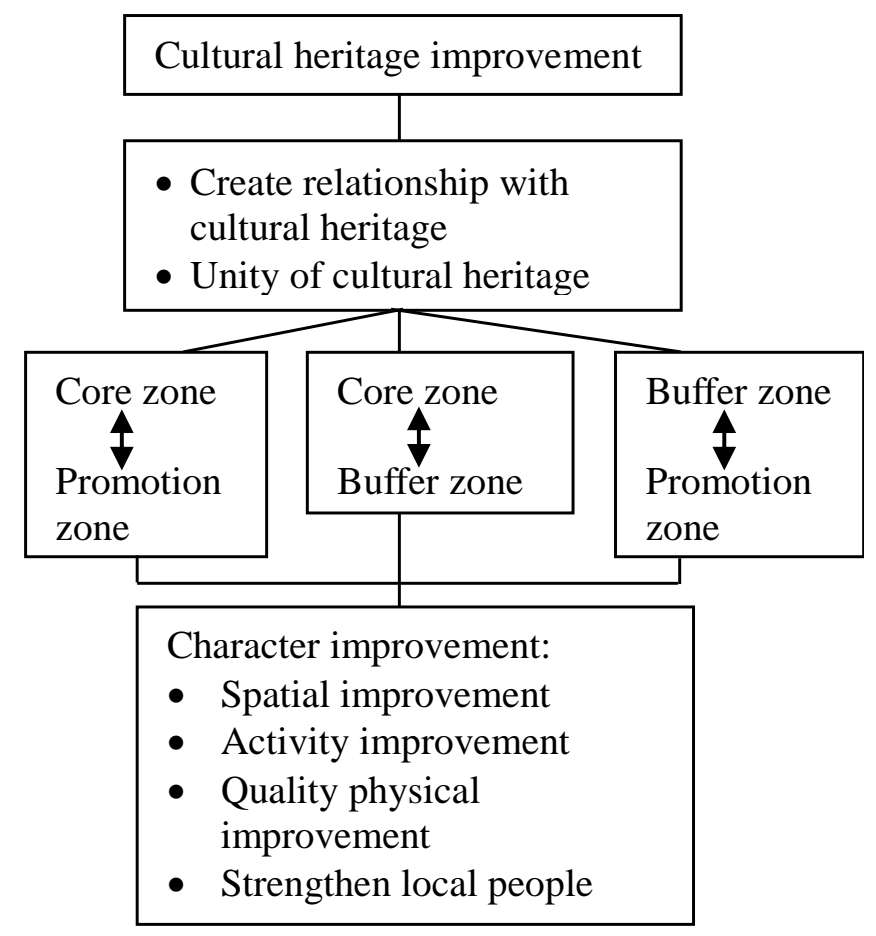

Fig. 6. Character improvement of cultural heritage 
When strengthening cultural space, it is not enough to just rely on the existence of a physical object. It is necessary to create a close relationship between the community and the support and optimization of indigenous organizations. Therefore, cultural heritage images require the support of local organizations as a social power base, so integration between objects, the placement of settlements, and indigenous organizations will be stronger than the simple physical arrangement of objects. The unique characteristics of a community can be embodied in objects with a physical identity, and these objects contribute to maintaining continuity within local settlements. This, in turn, contributes to the wealth of a city as a whole. Methodical planning of cultural heritage with a zoning approach that incorporates a core zone and buffer zone, along with customized, neighborhood-based spatial planning is necessary to achieve this. Therefore, although a considerable distance may affect the achievement of cultural space, it is not a major obstacle to achieving the optimization of cultural space in public housing because the promotion zone, the core zone, and the buffer zone are based on cultural values, which are based on the location of the ethnic community's early settlement area. In conclusion, three approaches to cultural planning are needed in the local ethnic community in Malalayang: 1) planning of three cultural heritage zones, a promotion zone, a core zone, and a buffer zone; 2) optimizing the relationship between the society and the indigenous organizations to promote cultural respect; and 3) strengthening the coastal zone. The process of improving cultural spatial planning is summarized in Table 9.

\section{Acknowledgments}

The authors are grateful to the Bantik peoples in Malalayang, Indonesia, and also to Mr. Denni Sege and Mr. Ferry None for their help and assistance in gathering information during the survey of the Bantik Settlement. Pingkan Peggy Egam would also like to thank the Indonesian Government, especially the Directorate General of Higher Education for scholarship of her doctoral studies. This paper was presented at the 4th International Conference on Engineering, Project, and Production Management, on October 23-25, 2013, in Bangkok, Thailand.

Table 7. Construction of spatial values

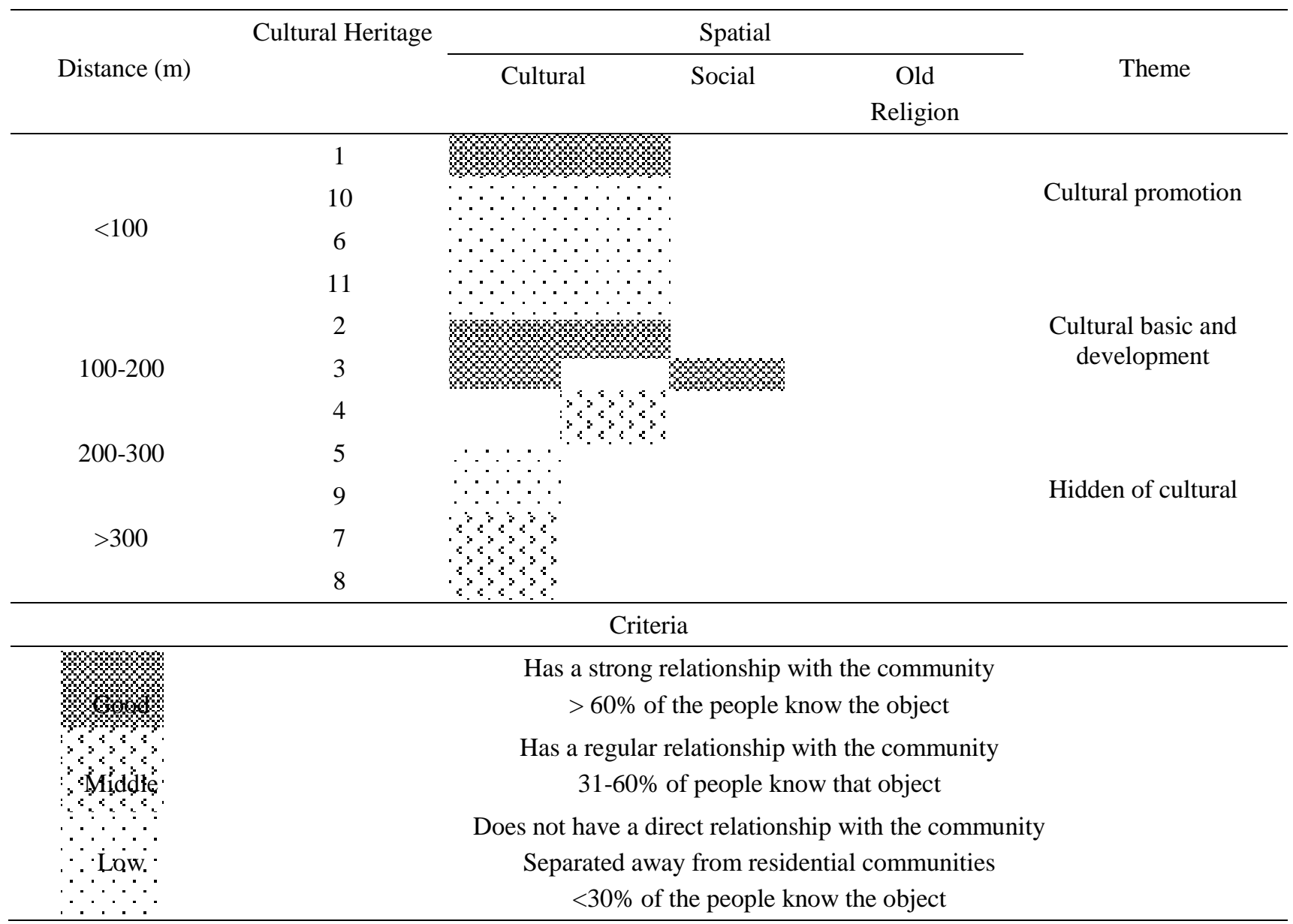


Table 8. Strengthening cultural heritage

\begin{tabular}{|c|c|c|c|c|c|}
\hline \multirow{2}{*}{$\begin{array}{l}\text { Distance } \\
(\mathrm{m})\end{array}$} & \multirow{2}{*}{$\begin{array}{l}\text { Cultural } \\
\text { heritage }\end{array}$} & \multicolumn{3}{|c|}{ Spatial relationship } & \multirow[b]{2}{*}{ Strengthen } \\
\hline & & Cultural & Social & $\begin{array}{c}\text { Old } \\
\text { Religion }\end{array}$ & \\
\hline \multirow{5}{*}{$<100$} & 1 & & & & - Has a strategic position and distance \\
\hline & 2 & & & & - Is in a location that has direct contact with the \\
\hline & 6 & & & & Ic \\
\hline & 10 & & & & - Is supported by good main road conditions \\
\hline & 11 & & & & - Is in a crowded location \\
\hline \multirow[t]{3}{*}{$100-200$} & 3 & & & & $\begin{array}{l}\text { - Is directly proximate to the main street in the } \\
\text { settlement }\end{array}$ \\
\hline & 4 & & & & $\begin{array}{l}\text { - Is supported by good main road conditions } \\
\text { - Has a specific cultural heritage }\end{array}$ \\
\hline & 5 & & & & - Strengthens the coastal location \\
\hline $200-300$ & 9 & & & & \\
\hline \multirow[t]{3}{*}{$>300$} & 7 & & & & $\begin{array}{l}\text { - Strengthens the periphery of the settlements } \\
\text { - Is in a separate location away from the Bantik } \\
\text { settlement }\end{array}$ \\
\hline & & & & & - Is surrounded by a non-Bantik settlement \\
\hline & 8 & & & & - Has a specific object \\
\hline
\end{tabular}

Table 9. Improvement of spatial planning

\begin{tabular}{|c|c|c|c|}
\hline \multicolumn{3}{|c|}{ Spatial planning } & Improvement \\
\hline - Strengthening & $\begin{array}{l}\begin{array}{l}\text { Distance (m) } \\
<100 \\
100-200\end{array} \\
200-300 \\
>300 \\
\text { f the coastal zone }\end{array}$ & $\begin{array}{l}\text { Promotion zone } \\
\text { Core zone } \\
\text { Buffer zone }\end{array}$ & $\begin{array}{l}\text { - Relationship: } \\
\checkmark \text { Creating a relationship between the promotion } \\
\text { zone, core zone and buffer zone } \\
\checkmark \text { Optimization of the relationship between society } \\
\text { and indigenous organizations for cultural respect } \\
\text { - Ethnic character: } \\
\checkmark \text { Physical arrangement of cultural heritage with } \\
\text { ethnic Bantik characteristics } \\
\text { - Inner coastal zone: } \\
\checkmark \text { Create cultural squares in the coastal zone } \\
\text { - Policy and surrounding areas: } \\
\checkmark \text { Design policy for integrated objects, surrounding } \\
\text { s and activities }\end{array}$ \\
\hline
\end{tabular}

\section{References}

Albrechts, L. (2004). Strategic (spatial) planning reexamined. Environment and Planning B: Planning and Design, 31, 743-758.

Bertolini, L. (1999). Spatial development patterns and public transport: The application of an analytical model in the Netherlands. Planning Practice and Research, 14(2), 199-210.

Chang, C. Y. and Chio, S. C. (2007). Environmental sustainability and the rebirth of cultural heritage: A case study of the Old Neihu Quarry in Taipei, Taiwan. Journal of Asian Architecture and Engineering, 6(1), 17-24.

Christensen, F. (2014). Understanding value changes in the urban development process and the impact of municipal planning. Journal of Land Use Policy, 36, 113-121. doi: 10.1016/j.landusepol.2013.07.005. Retrieved from http://www.sciencedirect.com on January 12, 2014. 
Cohen, I. A. (2004). Synergy between urban planning, conservation of the cultural built heritage and functional changes in the old urban center: The case of Tel Aviv. Journal of Land Use Policy, 22, 291-300. doi: 10. 1016/J.landusepol.2004.03.06. Retrieved from http://www.sciencedirect.com on December 12, 2013.

Egam, P., Mishima, N., and Subroto, W. S. (2012). Impact of Urban Development to Coastal Bantik Settlement in Malalayang, Indonesia. Proceedings of the 8th International Symposium , ILT, Indonesia, 554-560.

Egam. P. and Mishima, N. (2012). A Planning Approach of Population Movement for Local Coastal Bantik Community. Proceedings ICCC, Japan, 10(2), 101102.

European Commission. (1997). Compendium of European Planning Systems. Regional Development Studies Report 28. Office for Official Publications of the European Communities, Luxembourg. In: United Nation (2008). Spatial Planning. Key Instrument for Development and Effective Governance with Special Reference to Countries in Transition. Geneva, Switzerland, 1-6. Retrieved from http://www. sciencedirect.com on January 12, 2014.

Fernandes, J. R. and Chamusca, P. (2014). Urban policies, planning and retail resilience. Journal of Cities, 36, 170-177. doi: 10.1016/j.cities.2012.11.006.

Graham, B., Ashworth, G. J., and Tunbridge, J. E. (2000). A Geography of Heritage: Power, Culture and Economy. London: Hodder Arnold. In: Jimura, T. (2011). The impact of world heritage site designation on local communities: A case study of Ogimachi, Shirakawa-mura, Japan. Journal of Tourism Management, 32(2), 288-296. doi: 10.1016/j.tourman.2010.02.2005.

Grafland, N. (1991). Minahasa, Yayasan Parahita, Jakarta. 502-509.

Healey, P. (2006). Transforming governance: Challenges of institutional adaption and a new politics of space. European Planning Studies, (14) 3, 299-320.

Hejazi, M. (2008). The risks of cultural heritage in Western and Central Asia. Journal of Asian Architecture and Engineering, 7(8), 239-245.

Hewison, R. (1987). The heritage industry: Britain in a climate of decline. London: Methuen. In: Jimura, T. (2011). The impact of world heritage site designation on local communities.: A case study of Ogimachi, Shirakawa-mura, Japan. Journal of Tourism Management, 32(2), 288-296. doi: 10.1016/j.tourman. 2010.02.2005.

Higgins, M. (2007). The Cultural Space. ECCM Symposium "Productivity of Culture" in Athens. Retrieved from http://productivityofculture.org June 11, 2013.

Hui's, E. C. H., Lia. S. M., Wong. F. K. W., and Yu, Z. Y. K. H. (2012). Ethnicity, cultural disparity and residential mobility: Empirical analysis of Hong Kong. Journal of Habitat International, 36(1), 1-10. doi: $10.1016 /$ j.hanitatint.2011.08.003.

ICOMOS. (2002). International Cultural Tourism Charter. Principles and Guidelines for Managing Tourism at Places of Cultural and Heritage Significance. ICOMOS International Cultural Tourism Committee. Retrieved from http://www.esicomos.org. on June 10, 2013.
ICOMOS. (2008). Quebec Declaration on the Preservation of the Spirit of Place. ICOMOS, Paris. 1-6. Retrieved from http://www.international.icomos. org on June 15, 2013.

Jimura, T. (2011). The impact of world heritage site designation on local communities: A case study of Ogimachi, Shirakawa-mura, Japan. Journal of Tourism Management, 32(2), 288-296. doi: 10.1016/ j.tourman.2010.02.2005.

Kelly, E. D. and Becker, B. (2009). Community Planning: An Introduction to the Comprehensive Plan. Washington, DC, 133-142.

Kwack, D. (2004). The aspect of residents' evaluation and community forming. Journal of Asian Architecture and Engineering, 3(2), 311-318.

Landman. T. and Robinsin, N. (2009). The SAGE Handbook of Comparative Politics. SAGE Publications Ltd. In: Fernandes, J.R., Chamusca. P. (2014). Urban policies, planning and retail resilience. Journal of Cities, 36, 170-177. doi: 10.1016/j.cities.2012.11.006.

Larkham, P. J. (2003). The place of urban conservation in the UK reconstruction plans of 1942-1952. Planning Perspectives, 18(3), 295-324.

Li, T. L. (2007). A study of ethnic influence on the facades of colonial shop houses in Singapore: A case study of Telok Ayer in Chinatown. Journal of Asian Architecture and Engineering, 6 (1), 41-48.

Nas, P. J. M. (2007). Kota-Kota Indonesia. Gadjah Mada University Press, Jogyakarta, 640-658.

Nyseth, N. and Sognnaes, J. (2013). Preservation of old towns in Norway: Heritage discources, community processes and the new cultural economyc. Journal of Cities, 31, 69-75. doi: 10.1016/j.cities.2012.05.014.

Pacione, M. (2001). Urban Geography: A Global Perspective. London: Routledge. In: Jimura, T. (2011). The impact of world heritage site designation on local communities: a case study of Ogimachi, Shir akawa mur a, Japan. Journal of Tourism Management, 32(2) 288-296. doi: 10.1016/j.tourman.2010.02.2005.

Pendlebury, J. (2003). Planning the historic city: 1940s reconstruction plans in Britain. Town Planning Review, 74(4), 371-393.

Prinder, D. (2003). Seaport decline and cultural heritage sustainability issue in the UK coastal zone. Journal of Cultural Heritage, 4(1), 35-47. doi: 1016/S1296-2074 (03)00006-2.

Simmie, J. and Martin, R. (2010). The economic resilience of regions: Towards an evolutionary approach. Cambridge. Journal of Regions, Economy and Society, 3(1), 27-34.

Sumolang, S. (2010). History of Bantik, KURE. 5 (5), 5156.

Tewdwr-Jones, M., Morphet, J., and Allmendinger, P. (2006). The contested strategies of local governance: Community strategies, development plans, and local government modernization. Environment and Planning A, 38, 533-551.

United Nations. (2008). Spatial Planning. Key Instruments for Development and Active Governance with Special Reference to Countries in Transition. Geneva, Switzerland, 1-6. Retrieved from http:// www.sciencedirect.com on January 12, 2014.

Vaz, E., Cabral, P., Caeno, M., Nijkamp, P., and Painho, M. (2012). Urban heritage endangerment at the interface of future cities and past heritage: A spatial vulnerability assessment. Journal of Habitat 
International, 36(2), 287-294. doi: 10.1016/ j.habitatint.2011.10.007.

Wegener, M. (2001). New spatial planning models. Journal of Applied Earth Observation and Geo information, 3, 224-237.

Yunus, H. S. (2005). Manajemen Kota. Pustaka Pelajar, 55-59.

Yunus, H. S. (2006). Megapolitan: Konsep, Problematika dan Prospek. Pustaka Pelajar, 70-74.

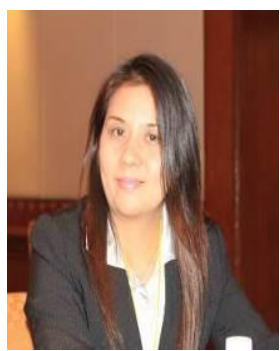

Pingkan Peggy Egam is a doctoral candidate at the Graduate School of Science and Engineering in the Department of Civil Engineering and Architecture at Saga University, Japan. She is a lecturer at Sam Ratulangi University in Manado, Indonesia. She is also a member of the International Association of Lowland Technology (IALT). This research was conducted to explore the significance of cultural spaces as a form of potential local social mobilization among the Bantik communities in Malalayang, Indonesia. Her research of the Bantik community was aimed at assisting the Bantik settlements with the process of surviving in the face of urban development pressures.

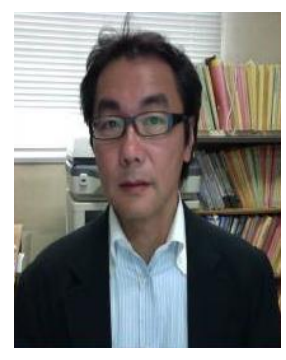

Nobuo Mishima is a professor at Saga University, in Saga, Japan. He received a B.E., M.E., and D.E. in urban engineering from the University of Tokyo, Japan in 1988, 1990, and 1995, respectively. He studied at the Technical University of Vienna from October 1990 to May 1992 as an exchange student and from October 1997 to September 1998 as a researcher. His primary field of study is urban design and planning. He has been a professor in the Graduate School of Science and Engineering at Saga University, Japan since February 2013, where he previously held the position of associate professor (from December 1998 to January 2013). His current research interests are focused on the content and spatial design of urban spaces, townscape design and control, and the preservation of historic places. Prof. Mishima is a member of the Architectural Institute of Japan and of the City Planning Institute of Japan. He was awarded a prize for the best presentation at the 1 st International Conference of ISHED. 